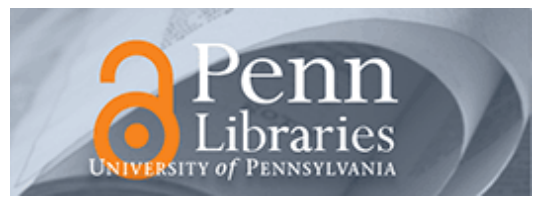

University of Pennsylvania ScholarlyCommons

$1-5-2013$

\title{
Negotiating Methodological Rich Points in the Ethnography of Language Policy
}

Nancy H. Hornberger

University of Pennsylvania, nancyh@gse.upenn.edu

Follow this and additional works at: https://repository.upenn.edu/gse_pubs

Part of the Anthropological Linguistics and Sociolinguistics Commons, Bilingual, Multilingual, and Multicultural Education Commons, Curriculum and Social Inquiry Commons, Educational Assessment, Evaluation, and Research Commons, Linguistic Anthropology Commons, and the Social and Cultural Anthropology Commons

\section{Recommended Citation}

Hornberger, N. H. (2013). Negotiating Methodological Rich Points in the Ethnography of Language Policy. International Journal of the Sociology of Language, 2013 (219), 101-122. http://dx.doi.org/10.1515/ ijsl-2013-0006

This paper is posted at ScholarlyCommons. https://repository.upenn.edu/gse_pubs/382

For more information, please contact repository@pobox.upenn.edu. 


\title{
Negotiating Methodological Rich Points in the Ethnography of Language Policy
}

\author{
Abstract \\ Building on Agar's (1996: 26) notion of rich points as those times in ethnographic research when \\ something happens that the ethnographer doesn't understand, methodological rich points are by \\ extension those points where our assumptions about the way research works and the conceptual tools \\ we have for doing research are inadequate to understand the worlds we are researching. When we pay \\ attention to those points and adjust our research practices accordingly, they become key opportunities to \\ advance our research and our under standings. Drawing for illustrative purposes on ethnographic \\ research on bi lingual intercultural education policy and practice in the Andes carried out by Indigenous \\ students for their Master's theses at the University of San Simón's Program for Professional Development \\ in Bilingual Intercultural Education for the Andean Region (PROEIB Andes) in Bolivia, I highlight \\ methodological rich points as they emerge across language policy texts, discourses and practices. \\ Framing the methodological rich points in the context of basic questions of re search methodology and \\ ethics, I borrow as organizing rubric the paradigmatic heuristic for sociolinguistic analysis first offered by \\ Fishman (1971: 219) and here adapted to the ethnography of language policy to ask: who researches \\ whom and what, where, how and why?
}

\section{Keywords}

sociolinguistics, data collection and analysis, ethnographic representation, thick description, emic and etic, language education research

\section{Disciplines}

Anthropological Linguistics and Sociolinguistics | Bilingual, Multilingual, and Multicultural Education | Curriculum and Social Inquiry | Education | Educational Assessment, Evaluation, and Research | Linguistic Anthropology | Social and Cultural Anthropology 


\title{
Nancy H. Hornberger \\ Negotiating methodological rich points in the ethnography of language policy*
}

\begin{abstract}
Building on Agar's (1996: 26) notion of rich points as those times in ethnographic research when something happens that the ethnographer doesn't understand, methodological rich points are by extension those points where our assumptions about the way research works and the conceptual tools we have for doing research are inadequate to understand the worlds we are researching. When we pay attention to those points and adjust our research practices accordingly, they become key opportunities to advance our research and our understandings. Drawing for illustrative purposes on ethnographic research on bilingual intercultural education policy and practice in the Andes carried out by Indigenous students for their Master's theses at the University of San Simón's Program for Professional Development in Bilingual Intercultural Education for the Andean Region (PROEIB Andes) in Bolivia, I highlight methodological rich points as they emerge across language policy texts, discourses and practices. Framing the methodological rich points in the context of basic questions of research methodology and ethics, I borrow as organizing rubric the paradigmatic heuristic for sociolinguistic analysis first offered by Fishman (1971: 219) and here adapted to the ethnography of language policy to ask: who researches whom and what, where, how and why?
\end{abstract}

Keywords: sociolinguistics; data collection and analysis; ethnographic representation; thick description; emic and etic; language education research

Nancy H. Hornberger: University of Pennsylvania. E-mail: nancyh@gse.upenn.edu

\footnotetext{
* An earlier version of this paper, encompassing applied linguistics research more broadly, and without the PROEIB Andes examples, appeared as Hornberger (2006). Versions of the present paper were presented at the Universidad de San Simón, Bolivia (June 2006), University of British Columbia (May 2009), University of Birmingham, UK (July 2009), the American Association for Applied Linguistics Annual Conference (March 2010), the University of Minnesota (June 2010), the 7th International Conference on Chinese Sociolinguistics (July 2010), and the University of Cape Town, South Africa (August 2010). I am grateful to those who invited and attended those talks, and to David Cassels Johnson and two anonymous reviewers for this IJSL issue, for their comments, critiques, encouragement and insights.
} 


\section{Introduction}

Methodological rich points are those times when researchers learn that their assumptions about the way research works and the conceptual tools they have for doing research are inadequate to understand the worlds they are researching. Methodological rich points make salient the pressures and tensions between the practice of research and the changing scientific and social world in which researchers work. When we pay attention to those points and adjust our research practices accordingly, they become key opportunities to advance our research and our understandings. ${ }^{1}$

I have borrowed and adapted the term methodological rich points from ethnographer Michael Agar's notion of “rich points" as those times in ethnographic research when something happens that the ethnographer doesn't understand, when "an ethnographer learns that his or her assumptions about how the world works, usually implicit and out of awareness, are inadequate to understand something that had happened" [in the corner of the world he or she is encountering] (Agar 1996: 31). Agar discusses rich points as one of three important pieces of ethnography: participant observation makes the research possible, rich points are the data you focus on, and coherence is the guiding assumption by which you seek out a frame within which the rich points make sense (Agar 1996: 32). Rich points, then, are points of experience that make salient the differences between the ethnographer's world and the world the ethnographer sets out to describe. Methodological rich points are, by extension, points of research experience that make salient the differences between the researcher's perspective and mode of research and the world the researcher sets out to describe.

Here I highlight several methodological rich points, drawing on ethnographic research on language policy, and in particular on a program of ethnographic research on Indigenous education in the Andes carried out in the master's degree program, or Maestría, at PROEIB Andes in Bolivia, a multiparty consortium effort sponsored by several Andean nations in the context of Bolivia's 1994 Education Reform and related language education policy initiatives in the participating countries (for a description of a related reform in Peru, see Valdiviezo, this issue). Bolivia's 1994 reform featured bilingual intercultural education ("educación intercultural bilingüe” EIB or “educación bilingüe intercultural” EBI) as a key component of a comprehensive transformation of Bolivia's educational system, includ-

1 Methodological rich points are akin to Eisenhart's (2001) muddles in educational ethnography. She discusses three, all reflected here to some degree: (1) the meaning of culture in postmodern times, (2) the increasing popularity of ethnographic research across disciplines, along with the backlash against it, and (3) the ethics of representation. 
ing introduction of all 30 of Bolivia's Indigenous languages alongside Spanish in all Bolivian schools. PROEIB Andes is the acronym for the Program for Professional Development in Bilingual Intercultural Education for the Andean Region established in 1997 at the University of San Simón in Cochabamba, Bolivia with the tripartite goal of graduate teaching, research and publication in Indigenous bilingual intercultural education across six Andean nations and Latin America more generally. At the core of PROEIB activities is the Maestría, a master's program in bilingual intercultural education for Indigenous students. ${ }^{2}$

The PROEIB Maestría is ethnically and linguistically diverse, enrolling Indigenous educators from the six Andean nations through a selection process involving their respective ministries of education, sponsoring universities and Indigenous organizations. Admissions criteria require that the applicant be a speaker of an Indigenous language who self-identifies as Indigenous and is endorsed by an Indigenous community or organization. The fourth cohort, from whose work I draw here, comprised 41 Indigenous educators representing at least 10 different Indigenous ethnicities and language varieties.

PROEIB students pursue an intense academic curriculum in four areas: language, culture, education and Indigenous language. Each of their five 21-week semesters of coursework entails a significant 4-8 week field component, culminating in extended ethnographic research for their master's theses in Indigenous communities and schools dispersed across all six national territories. I cite here several of the Maestría theses to illustrate methodological rich points in the ethnography of language policy, framed in the context of basic questions of research methodology and ethics. I use these examples from a cohort of novice researchers as illustrations of methodological rich points encountered by ethnographers of language policy more generally, be they novice or expert. I am not claiming that the students' (or their mentors') perspectives were explicitly challenged in these ways in every case, but rather that the examples from their research help illuminate methodological rich points that on occasion may challenge any of us undertaking ethnographic research on language policy and planning. As a sociolinguist, I borrow as organizing rubric the paradigmatic heuristic for sociolinguistic analysis first offered by Fishman as "who speaks (or writes) what language (or what language variety) to whom and when and to what end?” (1971: 219), here

2 I am indebted to PROEIB Andes founding director Luis Enrique López and to the PROEIB faculty, staff and students who have welcomed me warmly as visiting professor, colleague and participant observer since the beginnings of PROEIB (and before) and especially during my 2005-2006 sabbatical visits. My special thanks to the Maestría fourth cohort group and to the thesis writers whose work I cite here, with their permission. 
adapted to the ethnography of language policy to ask: who researches whom and what, where, how and why?

\section{Who researches whom in the ethnography of language policy?}

At the most basic level, ethnographers of language policy focus attention on policy-shaped/ policy-shaping texts, discourses and practices of language users - individuals and groups, teachers and students, community members and policy makers, among others. These participants are central to the ethnography of language policy and, as in all ethnographic research, participant-related methodological rich points arise around questions of authority, collaboration, reflexivity and representation.

Authority refers to the researcher's authority over the interpretation of the data - the right to claim that he or she has "got it right" in reporting findings. On what basis does the researcher have (or not have) authority to speak for the participants? Authority is closely linked to collaboration. "Ethnographic research is collaborative... . It's always been that way. ... What the new ethnography calls for is attention to the way collaborative work leads to the results" (Agar 1996: 16). The authority issue puts the spotlight on the ethnographer and the question of who studies whom, leading to questions about who is self and who is other, and even what is emic and what is etic (Agar 1996: 17, 21). I will say more about this below.

A key methodological theme in the emergence of critical ethnography over the past few decades has been that of critical reflexivity - "a complex dialectic between the researcher, the research process, and the research outcome(s)" (May 1997: 200). Critical reflexivity entails engaging reflectively not only with one's research constructs and data, and with informants' constructs, but also with one's own ideological biases as well as the sociohistorical structures shaping the research setting.

In sociolinguistics, methodological rich points around authority, collaboration, reflexivity, and representation have been forcefully and articulately raised in terms of the slogan "research on, for, and with subjects", put forward by Cameron et al. (1992). After first discussing issues of power and of positivist, relativist and realist paradigms of research, the authors introduce a distinction between an ethics-based approach (research on subjects), which seeks to balance the needs of a discipline in pursuit of knowledge with the interests of the people on whom the research is conducted; an advocacy-based approach (research on and for sub- 
jects), which despite its commitment to participants nevertheless still tends toward a positivist notion that there is one true account; and an empowermentoriented approach (research on, for and with subjects), which uses interactive, dialogic methods and seeks to take into account the subjects' research agenda, involve them in feedback and sharing of knowledge, consider representation and control in the reporting of findings, and take seriously the policy-making implications of the research. The authors clearly advocate the last approach and offer examples of attempts to implement it in their own research.

Educational ethnographer Reba Page speaks of a crisis in representation in qualitative research. She writes that increasing recognition of limits to "the qualitative claim that researchers could document and explain, fully and accurately, another's life-world as it is" (Page 2000: 5) presents at least two kinds of challenges and ethnographers' responses to them. There is a political challenge centering around whose representations are the ones put forward; this has given rise to new interdisciplinary alignments, fieldwork relations, and advocacy stances (Page 2000: 6-7). There is also what Page calls an aesthetic challenge around how knowledge is represented in texts, to which scholars have responded with "modes of reproduction that [give] more prominence to their own meaning-making, the artfulness of accounts, and the diverse 'voices' and alternate views of informants" in the form of dialogic scripts, collaborative authorship, autobiographical ethnographies, and even novels. The quest was for more "candid representations than conventional social science" offers, although these forms in turn raised questions as to whether the accounts were now too researcher-focused (Page 2000: 6).

Paying more attention to authority, collaboration, reflexivity, and representation in the ethnography of language policy may take a number of forms - it may be about working with multiple members of a research team; it may also be about relationships between researcher and researched; and may range from consultative to fully participatory relationships. It may be about collecting and analyzing data; it may also be about writing up and reporting findings. It is without doubt about reflecting critically on all of these, incorporating multiple voices in the research process and producing multi-voiced texts.

PROEIB Maestría student Amilcar Zambrana, in his ethnographic study of child socialization into potato production in a Bolivian Quechua community Socialización en torno a la producción de papa en niños de Piusilla 'Socialization of Piusilla children into potato production', settled on a method to maximize incorporation of local voices - oral history interviews organized around the life chronology of the interviewee rather than around the researcher's questions or objectives. In this way, he uncovered perspectives and experiences - such as one elder's self-taught analysis of the genetics of seed potatoes, or accounts of Indig- 
enous ways of calendar and time reckoning - that might have remained hidden because no one thought to ask. Similarly, Maestría researcher Ruth Catalán, in her ethnography of a participatory, community-controlled school in another Bolivian Quechua community - Encuentros y desencuentros: Luchando por una educación propia y participativa en una comunidad quechua de Bolivia 'Encounters and missed encounters: fighting for self-determination and participatory education in a Quechua community of Bolivia', sought to represent multiple and conflicting voices, even those with whom she did not agree, in the community's struggles over curricular and operational decisions in the school's governance. These voices included the community's own longstanding non-governmental organization, Junt'asqa Yachay Purichiq Ayllu (JYPA), with an activist heritage stretching back to early 20th century Indigenous education initiatives in the Andean highlands (cf. López 2005; Pérez 1962) and with whom the researcher as herself an Indigenous educator and activist was usually in agreement. The voices she captured also encompassed teachers divided among themselves between those trained by state normal schools and those from the community, as well as the departmental office of education and the national ministry, all of whom played decisive and sometimes conflictive roles. In both theses, the ethnographers negotiated methodological rich points of authority, collaboration, reflexivity, and representation by taking considerable care to reflect critically on their own ideological biases and to incorporate and represent multiple voices in their research and writing on school and community language policies.

\section{What do ethnographers of language policy research?}

Ethnographers of language policy are concerned with investigating the creation, interpretation, and appropriation of policy on language status, corpus, or acquisition in particular contexts. We are interested in discerning both top-down and bottom-up language policy processes and their interactions, and we find ethnography particularly suited to uncovering the indistinct voices, covert motivations, embedded ideologies, invisible instances, or unintended consequences of language policy emergent in context (Hornberger and Johnson 2011).

Language policy ethnographers often take up these language policy concerns as they play out in education - focusing on policy and planning around language teaching and learning, or language in learning and teaching (cf. Hornberger [2001] on educational linguistics). We may investigate, for example, policies on language learning and instructional practices in classrooms at elementary, sec- 
ondary or tertiary levels; on language acquisition and use in classroom interaction; or on methods of assessing what a language learner knows and can do. In every instance and whatever the context, it is precisely context that is crucial to analyzing, interpreting and generalizing ethnographic findings.

For sociolinguistic ethnographers and linguistic anthropologists of education, studying language and education in social and cultural context has always been the bedrock of research method, evident in such long established strands of work as the ethnography of communication - documenting and comparing ways of speaking (Hymes 1964, 1968; Philips 1983; Heath 1983), interactional sociolinguistics - revealing the multiple linguistic means by which we embed social meanings in interaction (Gumperz 1982), and microethnography - demonstrating the importance of situationally emergent social identity and co-membership (Erickson and Shultz 1982) (see Hornberger [1995] for a review of these three sociolinguistic approaches to school ethnography). Increasingly, these ethnographers frame their attention to context from a social constructivist view that "human reality is extensively reproduced and created anew in the socially and historically specific activities of everyday life” (Rampton [2000: 10], citing Giddens [1976, 1984]).

Duff (2006) for example, argues that "sociopolitical structure not only influences and mirrors, but is also constituted in" language learning and teaching "events and interactions in everyday classrooms" (Duff 2006: 77). She cites examples from her ethnography of language learning classrooms in Hungary to demonstrate the importance of taking into consideration all layers of context, including sociopolitical and historical structures, participants and their interests, classroom tasks and instructional practices, and participants' understandings of these, in order to analyze the language learning and teaching going on. She highlights that context both influences and is influenced by language education policy as enacted in the classroom.

Ethnographers of language policy pay ever more explicit attention to social constructionism, documenting patterns of language use and social relations in multilingual classrooms and communities, and exploring dimensions of multilingual classroom discourse that maintain or challenge the status quo in societal power relations (e.g. Arkoudis and Creese 2006; Blackledge and Creese 2010; Creese and Martin 2003; Heller and Martin-Jones 2001; Hornberger 1998, 2000, 2003; Jaffe 1999, 2003, 2007; Martin-Jones and Jones 2000; McCarty 2005; Wortham and Rymes 2003). Methodological rich points arise precisely around the social construction of voices, motivations, ideologies, and consequences of language policy emergent in context.

A number of PROEIB theses document the incorporation of local knowledges in the implementation and interpretation of national language policy, illuminat- 
ing ways unequal societal power relations are challenged in multilingual classroom discourse. Two PROEIB Maestría theses, focusing on teacher and student text production in primary schools of Quechua communities in Bolivia, unintentionally uncovered just such local knowledges in the classroom. Carmen García Mamani, in Estrategias de producción de textos por niños quechuas del ayllu Yura 'Strategies of text production by Quechua children in the highland community of Yura ayllu', found that teachers, in using the curricular modules of the 1994 reform complemented them with locally relevant pedagogical strategies such as inviting children's recounting of their daily lives in school assignments, or using a local discourse practice she called preguntas contrarias 'counter-questions' to generate children's reflection about social behavior. This latter was based on community elders' practice of admonishing parents by posing an undesirable behavioral pattern for their children and asking the parent if it is ok (“allinchu?"), after which parents respond no and state the positive alternative; García observed this discourse practice employed by teachers to stimulate students' writing, paralleling also the moral lessons of traditional Andean folktales featuring the fox, condor and other characters often behaving badly and earning their just deserts (cf. Chuquimamani 1983, 1984).

Clemente Cazón, in his thesis, Producción de textos escritos en quechua como L1: Un desafio para profesores y alumnos 'Written text production in Quechua as a first language: a challenge for teachers and students', shows how teachers in a lowland Quechua community draw on local knowledges and in particular on linguistic features specific to Quechua in working with students on text production under the bilingual intercultural education reform. For example, teachers highlight Quechua-specific pragmatic (metaphor), syntactic (discourse marker ari), morphological (inclusive/exclusive first person plural suffixes), and phonological (sound-symbol correspondence) features as resources for their students to draw on in their writing. The methodological rich point here centers around the researchers' encounter with and rendering of practices beyond those envisioned in their own research questions or the explicit intentions of the educational reform. The crux of the methodological rich point is that the researchers' categories of text production underwent redefinition as their research experience in classrooms made salient the difference between their concepts, as based perhaps on their prior experience and the reform's definitions, and the teachers' practices they set out to describe. In both cases, as well, the teachers' practices explicitly foregrounded Quechua-specific language features and discourse practices not traditionally valued in Bolivian classrooms. Ethnographers of language policy are strategically positioned to document just these kinds of locally constructed challenges to the historically unequal statuses of languages in schools. 


\section{Where do ethnographers of language policy research?}

Classrooms at all levels, district and state education administration offices, professional development settings, community sites of formal and non-formal education, and institutional, family and community settings more generally are usual venues for the ethnography of language policy. There is increasingly explicit attention to the multilingual, multicultural, multiliterate classroom and community contexts in which language learning, teaching and use take place, and methodological rich points here have to do with typicality and heterogeneity of sites or cases. Importantly, typicality may not always be the aim - atypical, unique, resilient or extreme cases or instances may purposely be sought out for the potential insight they offer (Duff 2006). Here, the methodological rich points lie in the researchers' choice of setting and their interpretation of its typicality and atypicality.

For example, PROEIB Maestría student Edgar Sanga Calamullo, in his language policy ethnography, Voces y el uso del aimara en la escuela EBI en una comunidad en transición 'Voices and uses of Aymara in an EBI school in a community in transition,' describes an Aymara community of Puno, Peru, with a long history of and teachers trained in EBI in Aymara and Spanish, but where nevertheless the children of the community don't want to speak the Indigenous language Aymara, whether in school or out. The children say they look forward to speaking Aymara when they are older, seemingly oblivious to the fact that if they don't speak it now, the intergenerational chain of transmission will be broken. In seeking an explanation for what strikes him as an atypical situation for an Aymara community, Edgar suggests a number of reasons including diverse perspectives in the community about what bilingual intercultural education is (from complete ignorance to deep knowledge), uncoordinated efforts by the Ministry of Education and other educational and community actors, the influence of Western culture via TV and the recent electrification of the community, youth who leave the community to become professionals and never return, and in general the rapid social transformation of the community due to its location on a main highway to the international border with Bolivia. While this may be an atypical case in its particular constellation of factors, it could also be considered a typical case precisely because of the complexity of tensions, ambiguities and paradoxes in linguistic, sociolinguistic, sociohistorical, and sociocultural identities and affiliations that bear on the uptake - or not - of bilingual intercultural education; and indeed because many of these same factors typically are involved across multiple similar contexts. 
Consider a Quechua community on the outskirts of Cuzco, Peru, which Neri Mamani Vilca terms the urban-rural frontier in her ethnography, El uso del quechua en una escuela EBI en una comunidad de frontera: Una tarea pendiente 'The use of Quechua in an EBI school in a frontier community: an unfinished task'. Mamani describes another paradoxical case of an Indigenous community with a long history of bilingual intercultural education and trained teachers. Here, there is rich and complex use of Quechua intra- and intergenerationally among adults and children in all community domains - including in the home and family, agricultural and pastoral, religious and festival, play and teasing domains, but nevertheless Quechua is not in use in the school. Neri considers the factors for and against Quechua use in the school: factors in favor include the existence of national policies and legal norms fostering bilingual intercultural education, the predominant use of Quechua in the community, and, from a theoretical point of view, the imperative for intergenerational transmission of a language if it is to remain viable; factors against include the loss of linguistic and cultural identity among Quechua speakers, the shame of speaking Quechua, the loss of Quechua use, and the second-class status of Quechua in the school - a scenario all too familiar across Quechua communities of the Andean highlands. The methodological rich points for these researchers - and for ethnographers of language policy in general - center on their choice and interpretation of the typicality/atypicality of their setting.

These cases also point to the heterogeneity of any particular site of language policy appropriation, interpretation and implementation - highlighting another locus of methodological rich points for the ethnography of language policy as it has evolved and developed over the past decades. The crux here is the changing nature - or perhaps more accurately, deepening understanding - of the speech community as research setting for the ethnographic study of language policy, language use and language learning. These methodological rich points have to do with a research tradition's revision of conceptual frames in the researchers' ongoing encounter with the world they describe. Defined in sociolinguistic work of the 1960 s as a community whose members share at least one language variety and the norms for its use (Hymes 1972: 54; Fishman 1971: 232), the underlying assumption in the concept is not uniformity of communicative resources and practices within a speech community, but rather patterned diversity of those resources and practices; as Hymes often repeated, it is "not replication of uniformity but organization of diversity" that is of interest (Hymes, University of Pennsylvania class lecture 1985, citing Wallace 1961). The task of the ethnography of a speech community is to "Take as context a community, investigating its communicative habits as a whole, so that any given use of channel and code takes its place as but part of the resources upon which the members of the community draw" (Hymes 1964: 3). 
In keeping with this emphasis on a holistic understanding of communicative resources at play, and in response to intensifying globalizing flows of capital, goods, people, images and discourses, ethnographic analysis of the speech community has moved toward ever greater recognition of a new "sociolinguistics of mobile linguistic resources" - wherein linguistic resources are seen as moving across scales, with shifts in function, structure and meaning, and through different orders of indexicality, organized in polycentric systems (Blommaert 2010: 22). Since the 1990s, there has been a shift from an exclusive focus on speech communities to a complementary focus on communities of practice and communicative practices, yielding "fine-grained and complex account[s] of imposition, collusion and struggle” (Rampton 2000: 12), where randomness and disorder are more important than system and coherence, and anomalous social difference is treated as central rather than peripheral (Rampton 2000: 9, 18).

Methodological rich points arise not only around the heterogeneous, mobile, multilingual nature of any one language policy site, but also around the diverse range of sites in which the ethnography of language policy is undertaken and which it is suited to illuminate - including school-and-community settings (e.g. Delgado-Gaitan 1990; Heath 1983; Hornberger 1988; McLaughlin 1992), out of school settings such as adult literacy programs, workplaces or religious settings (e.g. Heath and McLaughlin 1993; Knobel 1999; Hull and Schultz 2002; Spener 1994), bilingual and multilingual classroom settings around the world (e.g. Creese and Martin 2003; Heller and Martin-Jones 2001), language education professional development and practice settings (e.g. Arkoudis and Creese 2006; Brutt-Griffler and Varghese 2004; Hawkins 2004; Henning 2000; Pérez et al. 2003), and language education policy-making settings and activities (e.g. Canagarajah 2005b; Freeman 2004; Johnson 2004, 2009, 2010; Tollefson 1995, 2002; Tollefson and Tsui 2004).

Largely through the contributions of ethnographic research in such sites, there is growing recognition that language planning and policy-making happen as much at the micro-level of the classroom as at the macro-level of government (Ricento and Hornberger 1996; Ricento 2006). There is also greater acknowledgement of the tensions in language policies and practices, especially in postcolonial contexts undergoing simultaneous and contradictory processes of decolonization and globalization (Lin and Martin 2005). In confronting methodological rich points arising from the heterogeneity, mobility, diversity, scalelayering, indexicality and polycentricity of research sites, the ethnography of language policy is moving toward a more localized orientation that takes seriously the tensions, ambiguities, and paradoxes of language allegiances and sociolinguistic identities in order to understand (and construct) policies from the ground up (Canagarajah 2005a; see also Hornberger 1996). Ecological approaches, in 
particular, have been proposed as a way to do this (Canagarajah 2005a, 2005b; Hornberger 2003). I argue that these general trends in the ethnography of language policy have come in direct response to the salient differences researchers have encountered between their own perspectives and modes of research and the worlds they set out to describe.

\section{How do ethnographers of language policy collect, analyze and interpret data?}

As ethnographers of language policy, our primary data are bits or stretches of spoken or written language that make up the texts, discourses, and practices of language policy. These data are gathered primarily by observation, recording, elicitation and document collection; analyzed usually in some way for form, function and meaning; and interpreted within a variety of conceptual frameworks ranging from highly specified to more loosely configured.

Whatever the data collection and analysis methods or conceptual frameworks employed, methodological rich points regularly arise around sufficiency of data as a basis for inference and around the inferential relation between theory and data - central issues in ethnographic research, by definition interpretive and inductive in its search for patterns and understandings. How much data does one need to draw a credible inference? And how, exactly, does one infer from theory to data and back? The bases and processes of inference are an enduring locus of methodological rich points in ethnographic research.

One set of responses lies in ethnography's emic and holistic approach. The approach is emic in that the ethnographer attempts to infer the local point of view: to describe the ways of being, knowing, doing, situations and events as members understand and participate in them, i.e. as they make sense of them. It is holistic in that the ethnographer seeks to create a whole picture, one that leaves nothing unaccounted for and that reveals the interrelatedness of all the component parts (Hornberger 1992: 186; 1994: 688). Crucial to ethnography is the subjective involvement of the ethnographer in mediating between theory and data; and crucial to achieving a holistic and emic view are the processes of inference, interpretation and induction.

The emic/etic distinction so often invoked in ethnographic research was first proposed by Pike (1954), in direct parallel to the phonemic/phonetic distinction in phonology. In the study of human behavior, the etic standpoint is one situated outside the system studied, in which units and classifications are determined on the basis of existing knowledge of similar systems, and against which the particu- 
lar system is measured; while the emic standpoint is one situated inside the particular system studied, which views the system as an integrated whole, and in which units and classifications are determined during and not before analysis, and are discovered and not created by the researcher. Both standpoints are necessary and it is the movement back and forth between them that takes our understanding forward. Hymes speaks of Pike's three moments, etic-1, emic, etic-2, in terms of a "dialectic in which theoretical frameworks are employed to describe and discover systems, and such discoveries in turn change the frameworks" (Hymes 1990: 421). This dialectic movement from theory to data and back again is essential to the process of ethnographic interpretation, and it is the ethnographer who provides the inferential link.

PROEIB Maestría ethnographer Jaime Callizaya, in La evaluación de aprendizajes desde un enfoque intercultural 'Learning assessment in intercultural perspective', set out to investigate tests and testing instruments used by teachers in the Bolivian Aymara community of Irpa Chico, in light of EBI mandates calling for formative evaluation, dialogue assessment and self-evaluation. He found, however, that between observing in the school and reading evaluation theory, he began to broaden his concept of evaluation to the notion that learning is assessment and vice versa. So, instead of observing assessment in teaching and learning, he observed teaching/learning itself and extracted categories of assessment from there. In focusing on teacher-student interaction across classroom and other school settings, the kinds of questions teachers ask and whether, how and which children answer, he uncovered a whole gamut of assessment procedures, types and strategies at the school, including competitive sports and dance events. Here, it was the ethnographer's movement from etic to emic and back that enabled him to expand his categories of assessment beyond those typically expected in Andean classrooms or considered in the EBI to create a more holistic and emic account of what assessment looked like in this school.

Likewise, ethnographer Ricardo Rodríguez, setting out to understand La disciplina en un aula de EIB 'Discipline in an EIB classroom', found discrepant cases that caused him to revise his notion of discipline. For example, on one occasion when a child arrived late to school - that is, showed a lack of discipline in the school's terms - the teacher took time to question the child, thereby learning that he had had to take the family's cattle up to the hills that morning since his father had been suddenly called away on another matter. The teacher recognized that the child's tardiness was a result of a larger discipline issue, that of the child's family responsibilities and the family's livelihood. These layered notions of discipline came to form a part of Ricardo's findings from his ethnography of bilingual intercultural education in one particular rural Aymara classroom. 
In a recent essay on the development of conceptual categories in ethnographic research, Sipe and Ghiso emphasize the paradoxical nature of the interpretive process wherein "theoretical frameworks are essential to structuring a study and interpreting data, yet the more perspectives we read about, the greater the danger of overdetermining conceptual categories and the ways in which we see the data" (Sipe and Ghiso 2004: 473). Demonstrating and demystifying a process in which "induction and deduction are in constant dialogue" (Erickson 1986: 21), Sipe and Ghiso provide a detailed example of a breakthrough in Sipe's development of categories for his classroom data that came precisely from his reading Bakhtin (1984) at the time. In a commentary on their essay, Erickson underlines this point, noting that if Sipe had been reading someone else, e.g. Fish, Foucault or Habermas, the analysis might have gone in a different direction (Erickson 2004: 489).

Part of what drove Sipe to look for a further category in the first place was the existence of data that didn't fit the categories he had used up to that point outlier data that he became increasingly uncomfortable categorizing as simply "off-task" (Sipe and Ghiso 2004: 480). It was a question of sufficiency not so much in the amount of data as the kinds of data that posed an inferential challenge for Sipe. Erickson comments on this, too, noting that whereas quantitas is always first about "what amounts?" qualitas is about "what kinds?" (Erickson 2004: 487). Grappling with the data that didn't fit, the discrepant cases, Sipe achieved an interpretive breakthrough when he realized that these off-task sequences were actually instances of the "carnivalesque", in Bakhtinian terms. Erickson reinforces this point, emphasizing that Sipe's example demonstrates that neither ethnographic data themselves nor interpretive themes and patterns simply emerge, but rather must be found by the researcher (Erickson 2004: 486). The example also demystifies one researcher's grappling with methodological rich points around sufficiency of data and the inferential relation between theory and data.

Erickson applauds this demystification and takes the process one step further by considering alternative approaches to the "exhaustive analysis of qualitative data”, contrasting Sipe's bottom up approach with a top down approach that would "parse analytically from whole to part and then down again and again, successively identifying subsequent next levels and their constituents at that level of contrast [rather than] start by trying to identify parts first and then work up analytically from there" (Erickson 2004: 491). He prefers the top down approach himself in part because he thinks that is what social actors do, and in part because it invites "parsing all the way down on both sides of [the] analytic divide" (Erickson 2004: 491). Whether bottom up or top down, the quest is for holism. It is, ultimately, the holistic and emic quality of the ethnographer's account that grounds the interpretation and affords it generalizability. This brings us to the last part of our heuristic question. 


\section{Why do ethnography of language policy?}

The goal of the ethnography of language policy in education is, at its most fundamental, to understand, inform and transform policies and practices of language (in) learning and teaching. As in all research, generalizability is an important consideration, one that we tend to grapple with in terms of transferability and particularity. Transferability assigns responsibility to readers to determine whether findings apply to another context; variability across contexts is taken for granted, but if the ethnographer provides enough rich and detailed description and analysis of one local context, it should be possible for the reader familiar with another local context to sort out what findings might or might not transfer. In that regard, the greater the particularity of description and interpretation, the more likely it is that a reader will be able to determine whether these particular findings apply to another context. In this sense, the goal is not generalization or prediction but rather a search for particularity - what Geertz famously called "thick description" (Geertz 1973). Yet, methodological rich points arise around how much and what kinds of particularity and transferability are desired or needed.

PROEIB Maestría student Priscilla Sepúlveda carried out ethnographic research for her thesis on Incorporación de conocimientos mapuches en la escuela 'Incorporating Mapuche knowledge in school', in a school in Temuco, Chile where the school motto, "Let's improve our reading while learning our culture", reveals the school's commitment to incorporating Mapuche knowledge in students' learning. Yet, through her ethnography of language policy in this school, she uncovered characteristics that might in fact position Mapuche in an inferior status to Spanish or even transgress Mapuche norms. So, for example, she observed teachers' perhaps unconscious tendency to systematize Mapuche knowledge in non-Mapuche categories; and she noted transgressions of Mapuche cultural practices, when, on excursions to find and bring back local plants for their studies of Mapuche scientific knowledge, teachers nevertheless failed to teach the children to ask permission from the spirits of places and plants, the gen and newen, before picking the plants. Sepúlveda negotiates methodological rich points around particularity and transferability, explaining that her purpose in describing this particularity is not to suggest that this happens in all Mapuche schools, but that it could happen and that it behooves educators to be vigilant that our policies and practices actually transform curriculum as we intend.

In his ethnography in a school and community of Jujuy, Argentina - La escuela en la celebración del re-encuentro con el "nosotros indígena": Hacia la construcción intercultural de la identidad entre los kollas de la Quebrada de Humahuaca, Jujuy (Argentina) 'The school in celebration of the re-encounter with the 
"Indigenous we": toward intercultural construction of identity among the Kollas of Humahuaca, Jujuy (Argentina)', René Machaca was interested in how and to what degree the school and community construct Indigenous identities in a region where Quechua is no longer spoken but where Indigenous traces, roots, traditions and practices - not only the presence of a nearby archaeological ruin from Incan times, for example, but also practices such as playing the sikuri (a traditional Andean flute), singing coplas (a traditional Andean musical/poetic genre), and celebrating ceremonies of dedication to Pachamama ('mother earth' in Quechua) - stretch back for generations. Machaca negotiates methodological rich points around particularity and transferability, pointing out that the specifics of the case may not occur elsewhere, but the resources and strategies the participants use do. The transferability and generalizability of both these authors' ethnographies lie in their providing particular accounts informed by and contributing to the wider research literature on processes of minoritization - and revitalization - of Indigenous languages and identities through school practice.

\section{Final reflections}

We have talked about methodological rich points arising around authority and contextualization in relation to research questions, collaboration and representation in relation to research participants, heterogeneity and social construction in relation to research methods, demystification and holism in relation to analysis, and transferability and particularity in relation to implications. Underpinning all these are critical concerns that go beyond analyzing and interpreting findings to transforming the realities they describe; there is an explicit attention in the ethnography of language policy to power and inequality and the role of research and of the researcher in interrogating those (see also Hill and May, this issue). As Agar puts it in relation to critical ethnography, "you look at local context and meaning, just like we always have, but then you ask, why are things this way? What power, what interests, wrap this local world so tight that it feels like the natural order of things to its inhabitants?” (Agar 1996: 26). Or to paraphrase Pennycook on discourse analysis in applied linguistics research, the critical question becomes not only what language means and how that meaning is constructed across sentences, but also why those particular meanings out of all possible available meanings are expressed at that particular moment in time and place (Pennycook 1994: 116). As sociolinguistic research increasingly locates communicative practices as parts of larger systems of social inequality (Gal 1989: 347), it is natural to ask what we, as ethnographers of language policy, can do about transforming those practices and those inequalities. 
As we set about that task in our multiple and varied ethnographies of language policy, there are two more methodological rich points which to me seem basic for novice and expert researcher alike - humility and respect. Humility before the rich diversity of language learning and teaching practices and contexts we have the privilege to observe and seek to understand, and respect for the language teachers, learners, policymakers and users, both individuals and communities, who untiringly and insightfully ply their language and pedagogical knowledge and skills, day in and day out the world over.

Two final examples from PROEIB instantiate the humility and respect for the communities they research that in fact pervade all of the work of PROEIB faculty and students. Nereo Hancco Mamani took a sociolinguistic look at Quechua language use among children of Qquehar, Cusco, Peru, in his ethnography, Una mirada sociolingüística al uso de la lengua quechua por los niños de la comunidad campesina de Qquehuar en Cusco, Perú: Funciones comunicativas y demandas para su revitalización 'A sociolinguistic look at the use of Quechua by children of the peasant community of Qquehuar in Cusco, Peru: communicative functions and calls for revitalization'. Nereo had planned to use focus group methodology for his interviews, but once in the community, and drawing on his past work experience and his sense of what would work best, decided to use instead a method of language revitalization workshops, in which groups of children, parents, community leaders and teachers developed language revitalization proposals around categories he suggested (e.g. themes, materials, timeline, activities, strategies) and then presented to each other their proposals for strengthening the use of Quechua in family, school and community domains. Nereo found that this method provided him as researcher with information about uses and ideologies around Quechua, while at the same time providing the community with action plans. Such an approach reflects a research stance of humility, premised on the belief that the research participants know and can act to solve their own problems, as they themselves define them.

Another Peruvian, Bertha Año Huamán, decided to write her thesis in Quechua. Titled in Quechua, Kayhinatam runa simi qhipa simi hina 'Pukllasunchis' sutiyuq yachay wasipi yachachikuchkan 'How Quechua as a second language is taught at Pukllasunchis School', her ethnography focuses on the teaching of Quechua as second language in an urban private school in Cusco. She decided to write in Quechua, she said, in order to show it could be done, to extend Quechua use to another domain, and to expand Quechua vocabulary in authentic contexts. The effort this represents is an exceptional personal sacrifice that demonstrates deep respect for the Quechua language and its speakers - undertaken to raise the status of Quechua and transform educational policies and practices upheld by unequal societal power relations. 
The PROEIB ethnographers explore language policy and practice in education specifically with the goal of ascribing value to communicative resources brought by historically marginalized students, as did another groundbreaker half a world away in South Africa. Stein developed the Performing the Literacy Archive Project and the Photographing Literacy Practices Project with pre-service and inservice language teachers in Johannesburg, encouraging students' use of a range of representational resources in their meaning making, including linguistic, visual, gestural, sound and performance modes (Kress and Van Leeuwen 1996; Kress 1997), and reconfiguring "the existing values attached to representational resources" into "a broader notion of semiotic resources" (Stein 2004: 37). PROEIB Maestría ethnographers too are engaged in what Stein characterized as "the saying of the unsayable, that which has been silenced through loss, anger or dread, which enables students to re-articulate their relationships to their pasts. Through this process of articulation, a new energy is produced that takes people forward. I call this process of articulation and recovery re-sourcing resources" (Stein 2004: 39). The Maestría ethnographers' work is, as was Stein's, about transforming lives through language practices; and that, I believe, is what the ethnography of language policy is most fundamentally about.

\section{References}

Agar, Michael. 1996. Ethnography reconstructed: the professional stranger at fifteen. In M. Agar (ed.), The professional stranger, 1-51. New York: Academic Press.

Arkoudis, Sophie \& Angela Creese (eds.). 2006. Teacher-teacher talk: the discourse of collaboration in linguistically diverse classrooms. [Special issue]. International Journal of Bilingual Education and Bilingualism 9(4).

Bakhtin, Mikhail M. 1984. Rabelais and his world. Hélène Iswolsky (trans.). Cambridge, MA: MIT Press.

Blackledge, Adrian \& Angela Creese. 2010. Multilingualism. London: Continuum.

Blommaert, Jan. 2010. The sociolinguistics of globalization. New York: Cambridge University Press.

Brutt-Griffler, Janina \& Manka M. Varghese (eds.). 2004. Bilingualism and language pedagogy. Clevedon, UK: Multilingual Matters.

Cameron, Deborah, Elizabeth Frazer, Penelope Harvey, M. B. H. Rampton \& Kay Richardson. 1992. Researching language: issues of power and method. London: Routledge.

Canagarajah, A. Suresh. 2005a. Accommodating tensions in language-in-education policies: an afterword. In Angel Lin \& Peter Martin (eds.), Decolonisation, globalisation: language-ineducation policy and practice, 194-201. Clevedon, UK: Multilingual Matters.

Canagarajah, A. Suresh (ed.). 2005b. Reclaiming the local in language policy and practice. Mahwah, New Jersey: Lawrence Erlbaum.

Chuquimamani, Rufino. 1983. Unay Pachas: Qheshwa Simipi Qollasuyu Aranwaykuna, Vol. 1. Lima, Peru: Proyecto Experimental de Educación Bilingüe/Puno. 
Chuquimamani, Rufino. 1984. Unay Pachas: Qhishwa Simipi Qullasuyu Hawariykuna, Vol. 2. Cusco, Peru: Centro de Estudios Rurales Andinos "Bartolomé de las Casas".

Creese, Angela \& Peter Martin (eds.). 2003. Multilingual classroom ecologies: interrelationships, interactions and ideologies. Clevedon, UK: Multilingual Matters.

Delgado-Gaitan, Concha. 1990. Literacy for empowerment: the role of parents in children's education. London \& New York: Falmer Press.

Duff, Patricia. 2006. Beyond generalizability: contextualization, complexity and credibility in applied linguistics research. In Micheline Chalhoub-Deville, Carol A. Chapelle \& Patricia Duff (eds.), Inference and generalizability in applied linguistics: multiple perspectives, 65-95. Philadelphia: John Benjamins.

Eisenhart, Margaret. 2001. Educational ethnography past, present and future: ideas to think with. Educational Researcher 30(8). 16-27.

Erickson, Frederick. 1986. Qualitative methods in research on teaching. In Merlin C. Wittrock (ed.), Handbook of research on teaching, 3rd edn., 119-161. New York: Macmillan.

Erickson, Frederick. 2004. Demystifying data construction and analysis. Anthropology and Education Quarterly 35(4). 486-493.

Erickson, Frederick \& Jeffrey Shultz. 1982. Counselor as gatekeeper: social interaction in interviews. New York: Academic Press.

Fishman, Joshua A. 1971. The sociology of language: an interdisciplinary social science approach to language in society. In Joshua A. Fishman (ed.), Advances in the sociology of language, 217-237. The Hague: Mouton.

Freeman, Rebecca D. 2004. Building on community bilingualism. Philadelphia: Caslon Publishing.

Gal, Susan. 1989. Language and political economy. Annual Review of Anthropology 18. 345-367.

Geertz, Clifford. 1973. The interpretation of cultures: selected essays. New York: Basic Books.

Giddens, Anthony. 1976. New rules of sociological method. London: Hutchinson.

Giddens, Anthony. 1984. The constitution of society: outline of the theory of structuration. Berkeley: University of California Press.

Gumperz, John J. 1982. Discourse strategies. Cambridge: Cambridge University Press.

Hawkins, Margaret R. (ed.). 2004. Language learning and teacher education: a sociocultural approach. Clevedon, UK: Multilingual Matters.

Heath, Shirley B. 1983. Ways with words: language, life and work in communities and classrooms. New York: Cambridge University Press.

Heath, Shirley B. \& Milbrey McLaughlin (eds.). 1993. Identity and inner-city youth: beyond ethnicity and gender. New York: Teachers College Press.

Heller, Monica \& Marilyn Martin-Jones (eds.). 2001. Voices of authority: education and linguistic difference. Norwood, NJ: Ablex.

Henning, Elizabeth. 2000. Walking with "barefoot” teachers: an ethnographically fashioned casebook. Teaching and Teacher Education 16. 3-20.

Hornberger, Nancy H. 1988. Bilingual education and language maintenance: a Southern Peruvian Quechua case. Berlin: Mouton.

Hornberger, Nancy H. 1992. Presenting a holistic and an emic view: the Literacy in Two Languages project. Anthropology and Education Quarterly 23.160-165.

Hornberger, Nancy H. 1994. Ethnography. TESOL Quarterly 28(4). 688-690.

Hornberger, Nancy H. 1995. Ethnography in linguistic perspective: understanding school processes. Language and Education 9(4). 233-248. 
Hornberger, Nancy H. 1998. Language policy, language education, language rights: indigenous, immigrant and international perspectives. Language in Society 27(4). 439-458.

Hornberger, Nancy H. 2000. Bilingual education policy and practice in the Andes: ideological paradox and intercultural possibility. Anthropology and Education Quarterly 31(2). 173-201.

Hornberger, Nancy H. 2001. Educational linguistics as a field: a view from Penn's program on the occasion of its 25th anniversary. Working Papers in Educational Linguistics 17(1/2). 1-26.

Hornberger, Nancy H. 2006. Negotiating methodological rich points in applied linguistics research: an ethnographer's view. In Micheline Chalhoub-Deville, Carol A. Chapelle \& Patricia Duff (eds.), Inference and generalizability in applied linguistics: multiple perspectives, 221-240. Amsterdam \& Philadelphia: John Benjamins.

Hornberger, Nancy H. (ed.). 1996. Indigenous literacies in the Americas: language planning from the bottom up. Berlin \& New York: Mouton.

Hornberger, Nancy H. (ed.). 2003. Continua of biliteracy: an ecological framework for educational policy, research and practice in multilingual settings. Clevedon, UK: Multilingual Matters.

Hornberger, Nancy H. \& David C. Johnson. 2011. The ethnography of language policy. In Teresa L. McCarty (ed.), Ethnography and language policy, 273-289. New York: Routledge.

Hull, Glynda \& Katherine Schultz (eds.). 2002. School's out! Bridging out-of-school literacies with classroom practice. New York: Teachers College Press.

Hymes, Dell H. 1964. Introduction: toward ethnographies of communication. American Anthropologist 66(6). 1-34.

Hymes, Dell H. 1968. The ethnography of speaking. In Joshua A. Fishman (ed.), Readings in the sociology of language, 99-138. The Hague: Mouton.

Hymes, Dell H. 1972. Models of the interaction of language and social life. In John Gumperz \& Dell Hymes (eds.), Directions in sociolinguistics: the ethnography of communication, 35-71. New York: Holt, Rinehart \& Winston.

Hymes, Dell H. 1990. Epilogue to "The things we do with words". In Donal Carbaugh (ed.), Cultural communication and intercultural contact, 419-429. Hillsdale, NJ: Lawrence Erlbaum.

Jaffe, Alexandra. 1999. Ideologies in action: language politics on Corsica. Berlin \& New York: Mouton.

Jaffe, Alexandra. 2003. Talk around text: literacy practices, cultural identity and authority in a Corsican bilingual classroom. International Journal of Bilingual Education and Bilingualism 6(3/4). 202-220.

Jaffe, Alexandra. 2007. Codeswitching and stance: issues in interpretation. Journal of Language, Identity and Education 6(1). 53-77.

Johnson, David C. 2004. Language policy discourse and bilingual language planning. Working Papers in Educational Linguistics 19(2). 73-97.

Johnson, David C. 2009. Ethnography of language policy. Language Policy 8. 139-159.

Johnson, David C. 2010. Implementational and ideological spaces in bilingual education language policy. International Journal of Bilingual Education and Bilingualism 13(1). 61-79.

Knobel, Michele. 1999. Everyday literacies: students, discourse and social practice. New York: Peter Lang.

Kress, Gunther. 1997. Before writing: rethinking the paths to literacy. London: Routledge. 
Kress, Gunther \& Theo van Leeuwen. 1996. Reading images: the grammar of visual design. London: Routledge.

Lin, Angel \& Peter Martin (eds.). 2005. Decolonisation, globalisation: language-in-education policy and practice. Clevedon, UK: Multilingual Matters.

López, Luis Enrique. 2005. De Resquicios a Boquerones: La Educación Intercultural Bilingüe en Bolivia [From fissures to craters: intercultural bilingual education in Bolivia]. La Paz: PROEIB Andes y Plural Editores.

Martin-Jones, Marilyn \& Kathryn Jones (eds.). 2000. Multilingual literacies: reading and writing different worlds. Philadelphia: John Benjamins.

May, Stephen A. 1997. Critical ethnography. In Nancy H. Hornberger \& David Corson (eds.), Research methods in language and education, 197-206. Dordrecht: Kluwer Academic Publishers.

McCarty, Teresa L. (ed.). 2005. Language, literacy, and power in schooling. Mahwah NJ: Lawrence Erlbaum.

McLaughlin, Daniel. 1992. When literacy empowers: Navajo language in print. Albuquerque: University of New Mexico Press.

Page, Reba. 2000. The turn inward in qualitative research. In Bárbara M. Brizuela, Julie Pearson Stewart, Romina G. Carrillo \& Jennifer Garvey Berger (eds.), Acts of inquiry in qualitative research, 3-16. Cambridge, MA: Harvard Educational Review.

Pennycook, Alastair. 1994. Incommensurable discourses? Applied Linguistics 15(2). 115138.

Pérez, Bertha, Belinda Flores \& Susan Strecker. 2003. Biliteracy teacher education in the U.S. Southwest. In Nancy H. Hornberger (ed.), Continua of biliteracy: an ecological framework for educational policy, research and practice in multilingual settings, 207-231. Clevedon, UK: Multilingual Matters.

Pérez, Elizardo. 1962. Warisata: La Escuela-Ayllu. La Paz, Bolivia: E. Burillo.

Philips, Susan U. 1983. The invisible culture: communication in classroom and community on the Warm Springs reservation. New York: Longman.

Pike, Kenneth. 1954. Emic and etic standpoints for the description of behavior. In Kenneth Pike (ed.), Language in relation to a unified theory of the structure of human behavior, 37-72. The Hague: Mouton.

Rampton, Ben. 2000. Speech community. In Jef Verschueren, Jan Östman, Jan Blommaert \& C. Bulcaen (eds.), Handbook of pragmatics 1998, 1-34. Amsterdam: John Benjamins.

Ricento, Thomas K. (ed.). 2006. An introduction to language policy: theory and method. New York: Blackwell.

Ricento, Thomas K. \& Nancy H. Hornberger. 1996. Unpeeling the onion: language planning and policy and the ELT professional. TESOL Quarterly 30(3). 401-428.

Sipe, Lawrence R. \& Maria P. Ghiso. 2004. Developing conceptual categories in classroom descriptive research: some problems and possibilities. Anthropology and Education Quarterly 35(4). 472-485.

Spener, David (ed.). 1994. Adult biliteracy in the United States. Washington DC: Center for Applied Linguistics.

Stein, Pippa. 2004. Re-sourcing resources: pedagogy, history and loss in a Johannesburg classroom. In Margaret R. Hawkins (ed.), Language learning and teacher education: a sociocultural approach, 35-51. Clevedon, UK: Multilingual Matters.

Tollefson, James W. (ed.). 1995. Power and inequality in language education. New York: Cambridge University Press. 
Tollefson, James W. (ed.). 2002. Language policies in education: critical issues. Mahwah, NJ: Lawrence Erlbaum.

Tollefson, James W. \& Amy B. M. Tsui (eds.). 2004. Medium of instruction policies: which agenda? whose agenda? Mahwah, NJ: Lawrence Erlbaum.

Wallace, Anthony F. C. 1961. Culture and personality. New York: Random House.

Wortham, Stanton \& Betsy Rymes (eds.). 2003. Linguistic anthropology of education. Westport, Connecticut: Praeger. 